\title{
TINGKAT KEPUASAN WARGA TERHADAP KOMUNIKASI PARTISIPATIF PADA BENGKULU REGIONAL DEVELOPMENT PROJECT: KASUS DI DESA PONDOK KUBANG KECAMATAN PONDOK KELAPA KABUPATEN BENGKULU TENGAH
}

\author{
(CITIZEN SATISFACTION LEVEL IN THE PARTICIPATIVE \\ COMMUNICATION IN BENGKULU REGIONAL DEVELOPMENT PROJECT: \\ CASE IN PONDOK KUBANG VILLAGE PONDOK KELAPA SUBDISTRICT \\ CENTRE BENGKULU DISTRICT)
}

\author{
Gita Mulyasari \\ Jurusan Sosial Ekonomi Pertanian \\ Fakultas Pertanian Universitas Bengkulu
}

\begin{abstract}
The successful of Bengkulu Regional Development Project was very determined by the society's participation in all of the project activities. This research aimed to analyse satisfaction level felt by the society as the effect of participative communication in BRDP activities. The research was conducted in Village of Pondok Kubang Sub District of Pondok Kelapa District of Central Bengkulu. Sampling was conducted by Simple Random Sampling, number of respondents that would be collected as many as 25 respondents. The result showed satisfaction level that significant to the participative communication in BRDP activities.
\end{abstract}

Keywords: satisafction level, partisipave communication, BRDP

\section{PENDAHULUAN}

Konsep komunikasi pembangunan meliputi peran dan fungsi komunikasi (sebagai suatu aktivitas pertukaran pesan secara timbal-balik) di antara semua pihak yang terlibat dalam usaha pembangunan, terutama antara masyarakat dengan pemerintah, sejak dari proses perencanaan, kemudian pelaksanaan, dan penilaian terhadap pembangunan. Keberhasilan pembangunan berawal dari adanya komunikasi dalam pembangunan...

Peningkatan komunikasi pembangunan sangat penting untuk meningkatkan program-program pembangunan. Pengembangan komunikasi pembangunan ini perlu dilakukan dengan mengubah paradigma komunikasi pembangunan dari yang berciri linier (searah dari atas ke bawah) ke pola komunikasi yang berciri konvergen. Agar program yang akan dilaksanakan sesuai dengan aspirasi dan kebutuhan masyarakat. 
Keselarasan antara masyarakat dengan pemerintah yang sedang menjalankan program pembangunan lebih mudah direalisasikan apabila terdapat kehadiran komunikasi pembangunan. Pembangunan yang sebenarnya memiliki tujuan mulia dapat dikemas ke dalam pesan-pesan komunikasi yang perlu dimengerti, dipahami dan bahkan menjadi konsensus meskipun harus melewati proses tarik menarik bahkan konflik pada saat dikomunikasikan dengan masyarakat.

Salah satu prinsip dari program pembangunan adalah partisipasi. Program pembangunan harus selalu melihat partisipasi maksimal, dengan tujuan setiap orang dalam komunitas dapat secara aktif terlibat. Partisipasi aktif masyarakat dalam pelaksanaan program pembangunan memerlukan kesadaran warga masyarakat akan minat dan kepentingan yang sama. Untuk mewujudkan hal tersebut diperlukan peran aktif dari kelembagaan yang terdapat dalam masyarakat, terutama dalam menampung dan menyalurkan aspirasi masyarakat serta melakukan kontrol atas pelaksanaan berbagai kebijakan yang telah ditetapkan.

Bengkulu Regional Development Project (BRDP) merupakan salah satu program Pembangunan yang menggunakan prinsip partisipasi. Proyek Pembangunan Wilayah Bengkulu (BRDP) yang didanai Bank Dunia, dikembangkan dari konsep pengembangan wilayah terpadu. Program ini ditujukan untuk memecahkan masalah-masalah sosial, ekonomi, keterisoliran, produktivitas, dan pertumbuhan daerah melalui keterpaduan perencanaan, pelaksanaan, dan pengendalian, dengan memberikan peranan yang lebih besar pada masyarakat dan Pemerintah Daerah.

Komponen utama BRDP adalah kegiatan yang dilaksanakan melalui partisipasi masyarakat desa yang disebut Program Kegiatan Desa (PKD). Pengelolaan dilakukan oleh suatu organisasi Unit Pengelola Keuangan Desa (UPKD). PKD dikelola dengan pendekatan berdasarkan perencanaan dari bawah dan kebutuhan masyarakat (bottom up approach and demand driven), melalui pilihan menu kegiatan desa dengan penggunaan dana maksimum Rp 200 juta per desa selama proyek berlangsung hingga closing date (31 Agustus 2005).

Berhasil tidaknya pelaksanaan kegiatan proyek ini sangat ditentukan oleh partisipasi masyarakat dalam semua aktifitas proyek. Tanpa adanya partisipasi yang baik dari anggota maka kegiatan yang sudah dirancang sedemikian rupa tidak dapat berjalan sesuai dengan yang diharapkan dari pelaksanaan proyek. Untuk mengoptimalkan partisipasi masyarakat dalam program-program pembangunan (BRDP), diperlukan suatu komunikasi partisipatif yang baik dimana terjadi komunikasi timbal balik antara pihak-pihak yang terlibat dalam kegiatan BRDP dengan masyarakat. Salah satu prinsip kegiatan BRDP adalah adanya partisipasi masyarakat.

Proses pelaksanaan kegiatan BRDP merupakan suatu proses komunikasi partisipatif. Melalui tahapan yang dilaksanakan, diharapkan warga sebagai sasaran akhir akan terlibat secara langsung untuk memberikan saran, pendapat dan masukan kepada Tim Pelaksana BRDP mengenai berbagai permasalahan 
yang dihadapi masyarakat di desa tersebut, sehingga pada akhirnya dapat meningkatkan kesejahterannya.

Walaupun kegiatan BRDP ini telah disosialisasikan dan dilaksanakan, ternyata di lapangan menunjukkan bahwa kegiatan BRDP ini tidak sepenuhnya berjalan dengan baik. Masyarakat menganggap pihak pelaksana tidak konsisten dalam menerapkan proyek, karena banyaknya aturan yang berubah dan tidak disampaikan kepada warga. Selain itu masyarakat menganggap sosialisasi proyek yang dilakukan pada tahap awal oleh Pemerintah diterjemahkan sebagai pengumuman kepada masyarakat

Hasil desain ulang Bengkulu Regional Development Project (BRDP) yang dimonitor oleh masyarakat setempat bersama Yayasan Duta Awam dan NGO Mitra Lokal menunjukkan bahwa dukungan pelaksana kegiatan BRDP di lapangan tidak memuaskan warga. Hal ini menunjukkan bahwa dalam pelaksanaan kegiatan BRDP, komunikasi partisipatif masih belum berjalan dengan baik. Komunikasi partisipatif yang dilakukan mulai dari perencanaan, pelaksanaan dan evaluasi akan dipengaruhi oleh banyak faktor sehingga dapat berjalan dengan sepenuhnya. Berdasarkan uraian di atas, penelitian ini bertujuan untuk menganalisis tingkat kepuasan yang dirasakan warga sebagai dampak dari komunikasi partisipatif yang terjadi dalam kegiatan BRDP.

\section{METODE PENELITIAN}

Penelitian ini didesain sebagai penelitian survei yang bersifat deskriptif korelasional. Menurut Effendy (1993), desain penelitian survei adalah penelitian yang mengambil contoh dari suatu populasi dan menggunakan kuesioner sebagai alat pengumpulan data yang pokok. Lokasi penelitian adalah adalah Desa Pondok Kubang, Kecamatan Pondok Kelapa Kabupaten Bengkulu Tengah. Penentuan lokasi ini dilakukan secara purposive (sengaja) dengan pertimbangan bahwa desa ini merupakan desa sasaran BRDP yang memiliki anggota peminjam paling banyak. Pemilihan sampel penelitian yang merupakan anggota Unit Pengelola Keuangan Desa (UPKD) di lokasi penelitian yang terlibat dalam kegiatan BRDP dilakukan secara "simple random sampling". Pemilihan anggota kelompok UPKD dilakukan secara acak dengan mengambil 25 anggota UPKD yang terlibat dalam kegiatan BRDP. Anggota UPKD yang menjadi sampel adalah warga yang masih rutin membayar pinjaman modal bergulir BRDP. Distribusi variabel penelitian dianalisis menggunakan statistik deskriptif. Hubungan antar variabel di analisis dengan menggunakan uji korelasi Tau Kendall dengan menggunakan program SPSS 13 for Windows. 


\section{HASIL DAN PEMBAHASAN}

\section{Aktivitas Upkd Mitra Usaha Bersama}

Dana UPKD berasal dari dana proyek BRDP, dana bergulir, simpanan masyarakat (pokok + wajib). Dana ini diajukan untuk kegiatan ekonomi anggota UPKD Mitra Usaha Bersama. Jumlah dana keseluruhan yang telah digulirkan kepada anggota sebesar Rp. 200 juta yang terdiri dari dana bergulir dan dana sarana/prasarana desa. Kegiatan masyarakat desa untuk meningkatkan taraf hidupnya antara lain kegiatan usaha dibidang pertukangan,industri rumah tangga, jasa, pertanian dan perkebunan. Perguliran dana proyek BRDP kepada Desa Pondok Kubang dapat dilihat pada Tabel 1 di bawah ini.

Tabel 1. Jumlah dana dan peminjam dana bergulir di UPKD Mitra Usaha Bersama menurut tahapannya tahun 2004-2005

\begin{tabular}{llcc}
\hline \multirow{2}{*}{ Uraian } & \multicolumn{1}{c}{ Bulan } & \multicolumn{2}{c}{ Jumlah } \\
\cline { 3 - 4 } & & Dana (Rp) & Peminjam(orang) \\
\hline Tahap I & Februari 2004 & 16.750 .000 & 25 \\
Tahap II & Desember 2004 & 65.750 .000 & 48 \\
Tahap III & Juli 2005 & 67.560 .000 & 68 \\
\hline \multicolumn{2}{c}{ Jumlah } & 150.000 .000 & 141 \\
\hline
\end{tabular}

Sumber: Kantor UPKD Mitra Usaha Bersama, Tahun 2006

Tabel 1 memperlihatkan bahwa setiap tahap dana yang digulirkan proyek BRDP semakin meningkat. Meningkatnya dana pada setiap tahap memberikan arti bahwa pihak UPKD telah mendapatkan kepercayaan dari proyek BRDP untuk mengelola bantuan dana program kegiatan desa.

Selain dana bergulir, UPKD Mitra Usaha Bersama juga menerima dana proyek BRDP untuk pembangunan sarana dan prasarana, yaitu sebesar Rp. 50.000.000. Data selengkapnya dapat dilihat pada Tabel 2.

Tabel 2. Jumlah dana BRDP di UPKD Mitra Usaha Bersama menurut tahapannya tahun 2004

\begin{tabular}{|c|c|c|}
\hline Uraian & Bulan & Jumlah Dana (Rp) \\
\hline Tahap I & Mei 2004 & 30.000 .000 \\
\hline Tahap II & Juli 2004 & 20.000 .000 \\
\hline \multicolumn{2}{|c|}{ Jumlah } & 50.000 .000 \\
\hline
\end{tabular}

Sumber: Kantor UPKD Mitra Usaha Bersama, Tahun 2006

Sarana/prasarana desa yang dibangun adalah jalan desa Pondok Kubang 1500 meter, dimana kegunaannya untuk mempermudah dan memperlancar memasarkan hasil-hasil pertanian dan produk pemasaran lainnya. Kegiatan ini dilaksanakan selama 90 hari oleh TPSP2D (Tim Pelaksana Sarana Peningkatan Pembangunan Desa). 


\section{Desain Pinjaman UPKD Dan Pengembaliannya}

UPKD telah mendesain pinjaman atau kredit kepada anggota atau nasabah dengan menetapkan jumlah pinjaman kredit yang diajukan. Rata-rata pengajuan kredit maksimal Rp. 3.000.000. Jangka waktu pengajuan proposal hingga diverifikasi berkisar antara satu minggu sampai dengan satu bulan, sedangkan jangka waktu proposal setelah diverifikasi hingga pencairan berkisar antara tiga hari sampai satu bulan. Dalam pengembalian UPKD tidak memberikan masa tenggang, artinya apabila pada bulan tertentu meminjam maka pada bulan berikutnya nasabah diharuskan membayar cicilan pinjamannya.

Cara pencicilan pinjaman, UPKD menerapkan sistem bunga pinjaman dan pengembaliannya setiap bulan, hal ini dilakukan untuk mempercepat perputaran keuangan UPKD. Pengembalian dana titipan dilakukan secara rutin tiap bulan yaitu dengan membayar pokok pinjaman + bunga + simpanan wajib (Rp. 2.000/bulan). Adapun persentase pengembalian sampai dengan tahap sebelum pasca proyek BRDP adalah sebesar 100\%. Kegiatan UPKD yaitu pengembalian dana dari anggota terus digulirkan setiap bulan kepada anggota yang membutuhkan modal usaha pertanian maupun usaha lainnya. Dengan cara pengembalian setiap bulan, maka jangka waktu pelunasan pinjaman UPKD biasanya menetapkan 12 bulan hingga 24 bulan dengan tingkat bunga tetap.

\section{Tingkat Kepuasan Warga Terhadap Kegiatan BRDP}

Kepuasan warga terhadap kegiatan BRDP merupakan tingkat perasaan seseorang setelah membandingkan kinerja atau hasil yang dirasakannya dengan harapannya. Kepuasan warga akan terpenuhi apabila proses penyampaian pesan dari komunikator kepada warga sesuai dengan apa yang dipersepsikan warga. Analisis hubungan dilakukan untuk melihat apakah ada hubungan yang nyata antara komunikasi partisipatif dalam kegiatan BRDP dengan tingkat kepuasan warga.

Analisis uji Kendall antara komunikasi partisipatif warga dengan tingkat kepuasan yang dirasakan warga dalam kegiatan BRDP disajikan pada Tabel 3 berikut ini.

Tabel 3. Koefisien Tau-Kendall antara komunikasi partisipatif dengan tingkat kepuasan warga terhadap kegiatan BRDP di Desa Pondok Kubang

\begin{tabular}{clc}
\hline No. & \multicolumn{1}{c}{ Variabel } & Tingkat Kepuasan Warga (Y2) \\
\hline 1. & Komunikasi Partisipatif (Y1) & $0,300^{*}$ \\
2. & Tahap perencanaan (Y1.1) & 0,224 \\
3. & Tahap pelaksanaan (Y1.2) & 0,296 \\
4. & Tahap evaluasi (Y1.3) & 0,238 \\
\hline \multicolumn{2}{c}{ * signifikan pada taraf 0,05 }
\end{tabular}


Tabel 3 menunjukkan hasil analisis dengan melihat masing-masing peubah pada variabel komunikasi partisipatif, maka diperoleh bahwa komunikasi partisipatif yang terjadi pada tahap perencanaan, tahap pelaksanaan dan tahap evaluasi tidak memiliki hubungan yang nyata dengan tingkat kepuasan warga terhadap BRDP. Nilai koefisien korelasi Tau-Kendall menunjukkan bahwa tingkat kepuasan warga terhadap BRDP tidak dipengaruhi oleh faktor-faktor komunikasi partisipatif yang terjadi pada tahap perencanaan, tahap pelaksanaan dan tahap evaluasi.

Tetapi jika analisis langsung menggunakan nilai keseluruhan dari variabel komunikasi partisipatif, diperoleh bahwa komunikasi partisipatif dalam kegiatan BRDP memiliki hubungan yang nyata dengan tingkat kepuasan warga. Artinya, warga merasa puas jika keterlibatan mereka untuk mendorong komunikasi partisipatif dalam kegiatan BRDP semakin tinggi.

Peubah komunikasi partisipatif merupakan satu kesatuan dari tahap perencanaan, tahap pelaksanaan dan tahap evaluasi. Ketiga tahap ini mendorong suatu komunikasi partisipatif yang berhubungan nyata dengan tingkat kepuasan warga terhadap BRDP di Desa Pondok Kubang. Warga desa yang berpartisipasi aktif pada kegiatan BRDP akan merasa puas dengan hasil BRDP nantinya. Karena hasil BRDP tersebut merupakan keputusan warga desa yang telah dimusyawarahkan sejak tahap perencanaan, tahap pelaksanaan dan tahap evaluasi. Selain itu, warga desa akan lebih merasa memiliki jika pembangunan yang dilakukan BRDP merupakan hasil aspirasi warga desa.

Sebaliknya, jika warga desa tidak berpartisipasi secara aktif dalam kegiatan BRDP maka mereka tidak akan merasa puas dengan hasil pembangunan BRDP nantinya. Pembangunan desa dari BRDP tersebut bukan merupakan hasil sumbangan pikiran dan musyawarah warga desa. Mereka tidak merasa memiliki hasil pembangunan tersebut. Pembangunan jalan desa yang dibiayai oleh dana BRDP bukan merupakan hasil dari aspirasi dan keputusan bersama warga desa, sehingga sebagian besar warga desa merasa kecewa dan tidak puas dengan kinerja pengurus UPKD dan pengurus POKJA selama ini.

\section{Dampak Program Modal Bergulir BRDP terhadap Kehidupan Warga Desa}

\section{a. Meningkatkan Usaha Produktif}

Program dana bergulir (revolving funds) diberikan kepada warga desa untuk membantu mereka dalam meningkatkan usaha produktif sehingga kesejahteraan dapat meningkat dan sekaligus mengurangi tingkat kemiskinan. Hasil wawancara di lapangan juga menunjukkan bahwa masyarakat sangat terbantu dengan adanya program dana bergulir yang diberikan BRDP.

\section{b. Penurunan Jumlah Keluarga Miskin}


BRDP dengan program-programnya seperti dana bergulir (micro finance scheme), investasi sarana dan prasarana (jalan desa), memberikan dampak positif dalam meningkatkan mobilitas aktivitas ekonomi masyarakat desa. Perputaran uang meningkat seiring dengan mobilitas ekonomi masyarakat. Desa sudah tidak terisolir dan memudahkan saluran distribusi produk hasil pertanian. Biaya transportasi dan biaya produksi lainnya menjadi lebih rendah sehingga dapat meningkatkan keuntungan.

Kendati semenjak kehadiran BRDP jumlah keluarga miskin menurun, tidak dapat dipastikan penyebab penurunan ini dikarenakan semata-mata oleh program BRDP. Banyak faktor-faktor lain yang diduga ikut memiliki pengaruh dalam penurunan jumlah keluarga miskin, seperti faktor perkembangan ekonomi daerah, nasional atau regional. Bagi warga yang berprofesi sebagai petani sawit atau karet, pendapatan mereka dapat dipengaruhi oleh harga jual sawit atau karet yang bergantung pada harga jual di pasar komoditi internasional.

\section{c. Memperluas Kewirausahaan}

Salah satu program Pemerintah khususnya di bidang sosial ekonomi adalah mengentaskan kemiskinan. Melalui BRDP yang disponsori Bank Dunia, pemerintah berharap derajat warga desa dapat terangkat melalui pola pinjaman dana bergulir. Pola pinjaman dana bergulir yang diberikan kepada warga untuk meringankan mereka dalam upaya meningkatkan usaha. Pinjaman bergulir ini nantinya dapat dinikmati oleh seluruh lapisan anggota warga desa yang membutuhkan modal kerja. Keuntungan usaha yang diperoleh digunakan untuk memenuhi kebutuhan primer dan sekunder, seperti konsumsi seharihari, sandang, biaya perumahan, biaya pendidikan, dan kesehatan. Namun keuntungan juga digunakan untuk menambah modal dan akan dapat meningkatkan hasil produksi.

\section{d. Dampak Fisik BRDP}

Salah satu bentuk kegiatan yang dilakukan BRDP dalam rangka meningkatkan kesejahteraan masyarakat adalah pemberian dana untuk pembangunan sarana dan prasarana seperti sarana air bersih, jalan, jembatan dan irigasi. Di Desa Pondok Kubang dilaksanakan kegiatan pembangunan jalan desa. Berdasarkan hasil pengamatan dan survey di lapangan, kegiatan pembangunan jalan desa ini memberikan manfaat besar bagi warga terutama warga desa Pondok Kubang dan desa sekitarnya.

Manfaat yang diperoleh dari pembangunan jalan desa adalah memperlancar arus barang dan orang dari dan ke tempat usaha pertanian, meningkatkan volume arus barang dan orang, menghemat biaya transportasi dan waktu tempuh, meningkatkan harga tanah kebun 
dan sawah yang sebelumnya lokasinya terisolir, meningkatnya jenis alat transportasi, dan meningkatkan semangat warga untuk beryusaha, terutama usaha pertanian sehingga hasil pertanian meningkat.

\section{e. Dampak terhadap Kelompok Sosial}

BRDP merupakan salah satu bentuk kelompok sosial yang ada di desa selain LKMD, PKK, kelompok tani, dan sebagainya. Keberadaan BRDP secara tidak langsung telah mengaktifkan kembali aktivitas kelompok sosial di desa. Kelompok sosial merupakan wadah yang terdiri dari kumpulan warga yang bertujuan untuk memecahkan masalah-masalah yang berhubungan dengan masyarakat itu sendiri. Pada beberapa tahun sebelum BRDP terbentuk di desa. Kelompok sosial warga belumlah aktif seperti sekarang. Kelompok warga desa aktif masih dalam hal sebatas menyambut program-program pembangunan yang dilakukan pemerintah. Salah satu faktor penyebab keadaan ini adalah rendahnya pendapatan rumah tangga warga yang berada pada garis kemiskinan, bahkan ada yang di bawah garis kemiskinan. Pendapatan tersebut dari tahun ke tahun tidak meningkat, sehingga waktu luang cenderung mereka gunakan untuk memperoleh pekerjaan tambahan, yang hasilnya dapat disumbangkan untuk memenuhi kebutuhan rumah tangga.

\section{Dampak Negatif Program Modal Bergulir BRDP}

Dalam pelaksanaan program BRDP, ditemukan beberapa dampak negatif seperti:

Ketergantungan masyarakat terhadap bantuan Pemerintah. Meski pola pembiayaan yang dilakukan oleh BRDP merupakan konsep baru yang dikenalkan oleh Bank Dunia, micro finance, yang lebih menekankan kepada kemampuan individu untuk mengelola usaha, masih ada warga yang menganggap bahwa kredit bergulir tersebut sebagai hibah. Tingginya ketergantungan warga terhadap bantuan pemerintah membuat mereka akan kesulitan untuk mengembangkan usaha produktif mereka. Ketergantungan ini juga dapat menghambat semangat swadaya warga yang sangat diperlukan dalam usaha peningkatan infrastruktur ekonomi pedesaan. Di samping itu, ketergantungan warga desa terhadap bantuan pemerintah juga akan menghambat nilai-nilai kewirausahaan yang telah dikenalkan oleh proyek.

Kecemburuan sosial. Pelaksanaan program BRDP juga memungkinkan timbulnya kecemburuan bagi warga non penerima dana bergulir karena hanya sedikit warga yang bisa menikmatinya. Hasil pengamatan di lapangan juga memperlihatkan bahwa sebagian warga non penerima bantuan menganggap bahwa proses penilaian usulan proposal usaha tidak berjalan dengan jujur dan transparan. Sebagian warga non penerima menganggap bahwa penerima bantuan dana bergulir sebagian adalah orang-orang yang dekat dengan pengurus. Pelaksanaan program BRDP juga menimbulkan kecemburuan sosial bagi desa-desa yang tidak mendapatkan program BRDP. Warga di Desa Lubuk 
Lagan, Kabupaten Seluma, misalnya, menggugat mengapa desa mereka tidak dimasukkan sebagai desa binaan BRDP.

\section{Kendala yang Dihadapi Pengurus UPKD}

Berbagai kendala dan hambatan dihadapi oleh pengurus UPKD dalam menjalankan roda organisasi, baik dalam proses perencanaan, pelaksanaan dan evaluasi UPKD (Tabel 4). Secara umum kendala utama yang dirasakan adalah masalah tunggakan kredit. Hal ini berakibat pada lambatnya perputaran dana dalam warga itu sendiri, sehingga dana yang ada relatif sulit berkembang. Kendala-kendala yang ada tersebut telah dilakukan berbagai upaya oleh pengurus baik pendekatan pribadi untuk melakukan penagihan maupun memberikan penjelasan kepada nasabah tentang sifat pinjaman bukan hibah murni Pemerintah, tetapi merupakan dana pinjaman yang harus dibayar.

Tabel 4. Kendala yang dihadapi dan solusi yang dikemukakan oleh pengurus UPKD

\begin{tabular}{|c|c|c|}
\hline No. & Kendala Yang Dihadapi & Solusi \\
\hline 1. & $\begin{array}{l}\text { Tunggakan anggota disebabkan: } \\
\text { a) masih adanya anggapan } \\
\text { bahwa dana adalah cuma- } \\
\text { cuma } \\
\text { b) b.nasabah terpengaruh oleh } \\
\text { nasabah desa lain yang } \\
\text { pengembalian pinjamannya } \\
\text { macet } \\
\text { c) kurang aktifnya poka sehingga } \\
\text { pengurus agak kewalahan } \\
\text { d) adanya anggapan pengurus } \\
\text { UPKD kurang serius } \\
\text { Berakibat: } \\
\text { a) tertunda pemberian pinjaman } \\
\text { kepada nasabah yang lancer } \\
\text { pengembaliannya } \\
\text { b) b. perguliran dana menjadi } \\
\text { macet }\end{array}$ & 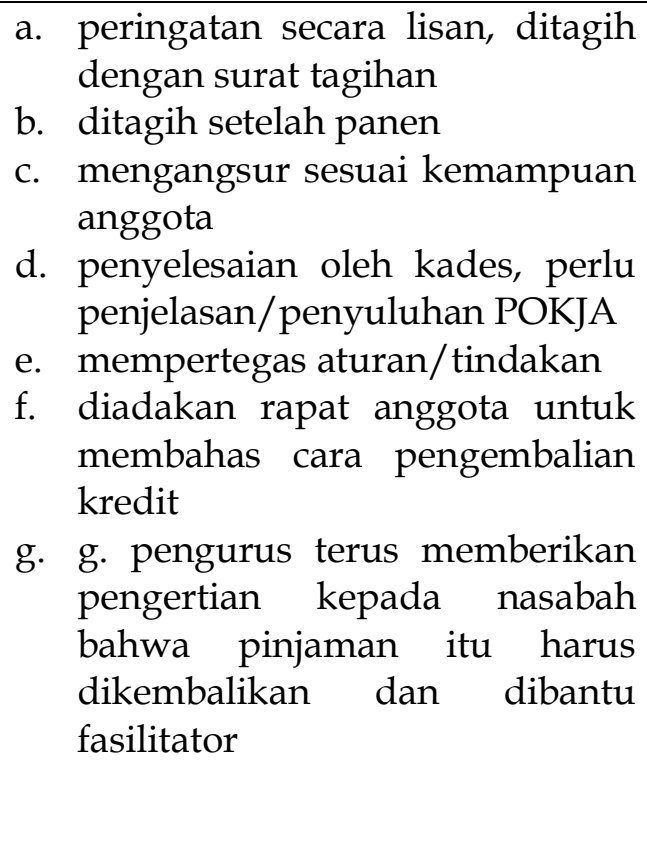 \\
\hline 2. & $\begin{array}{l}\text { Masyarakat belum mengerti } \\
\text { tentang UPKD }\end{array}$ & Pendekatan secara pribadi \\
\hline 3. & $\begin{array}{l}\text { Hubungan pengurus UPKD } \\
\text { dengan aparat desa dan BPD yang } \\
\text { tidak jelas }\end{array}$ & Merencanakan rembug desa \\
\hline $\begin{array}{l}4 . \\
5 .\end{array}$ & $\begin{array}{l}\text { Beragam pendapat } \\
\text { Perguliran dana yang masih } \\
\text { kekurangan modal }\end{array}$ & $\begin{array}{l}\text { Bermusyawarah mufakat } \\
\text { Pengurus UPKD/POKJA akan } \\
\text { mengajukan SP2D secepatnya }\end{array}$ \\
\hline
\end{tabular}




\section{SIMPULAN DAN SARAN}

Tingkat kepuasan warga berhubungan nyata dengan komunikasi partisipatif pada kegiatan BRDP jika warga terlibat secara aktif pada tahap perencanaan, pelaksanaan dan evaluasi. Artinya, jika komunikasi partisipatif pada tahap perencanaan, pelaksanaan dan evaluasi warga secara aktif berpartisipasi maka warga merasa puas dengan kegiatan BRDP yang dilaksanakan di Desa Pondok Kubang. Keterlibatan warga pada tahap perencanaan, pelaksanaan dan evaluasi, membuat warga merasa puas terhadap kegiatan BRDP di Desa Pondok Kubang.

Agen pendamping perlu lebih aspiratif melalui komunikasi dua arah dan berorientasi kepada kebutuhan warga desa, sehingga warga desa memiliki kemauan untuk lebih partisipatif dalam kegiatan BRDP. Artinya, agen pendamping harus memperhatikan kepentingan warga desa. Agen pendamping pun harus lebih jujur dan transparan dalam pelaksanaan kegiatan BRDP.

\section{DAFTAR PUSTAKA}

BRDP. 2004. Buku Panduan UPKD Program Kiegiatan Desa. Badan Perencanaan Pembangunan Daerah BRDP Propinsi Bengkulu. Bengkulu.

BRDP. 2006. Laporan Akhir Tahun Program Kegiatan Desa. Unit Pengelola Keuangan Desa (UPKD) Propinsi Bengkulu. Bina Swadaya. Bengkulu.

Effendy. O.U 1993. Ilmu Komunikasi Teori dan Praktek. Bandung: Remaja Rosdakarya. 